\title{
Fred ved ret?
}

\section{Henrik Døcker}

\section{Forsøgene på at tvinge staterne til forhandlings- bordet i stedet for at gå i krig med hinanden blev først rigtig et internationalt anliggende for godt 100 år siden, da 'fredssagen' kom på mode}

I begyndelsen var magten. Og magten var hos fyrsten. Og fyrstens ord var lov.

Sådan kan man passende indlede en slags historie om tidernes begyndelse - indtil moderne statsteorier om magtens tredeling, demokratiske forfatninger, internationalt samarbejde og tilhørende menneskeretsbeskyttelse vandt frem. Fra den florentinske politolog Niccoló Machiavellis bog Fyrsten til den franske dommer Montesquieus Om lovenes ånd $\mathrm{og}$ frem til $\mathrm{FN}$-Verdenserklaringen om Menneskerettigheder er der imidlertid store spring.

\section{Folkerettens 400-årige rødder}

Den moderne retsstat blev formet over den læst, der hedder magtens tredeling, nemlig i en lovgivende, udøvende og dømmende magt; to verdenskrige affødte et behov for universelt at sikre borgernes rettig- heder inden for staternes egne grænser. Men retsstaten skulle også være et internationalt ideal. Man kan sige, at lige som de tre statsmagter med den amerikanske konstitutionalist James Madisons ord skulle holde hinanden i 'skak og balance', således skulle staterne efter 1945 også føle et international ansvar for menneskerettighederne, dvs. kere sig om deres overholdelse både i deres eget land og i andre lande.

Der går på en måde en linje fra det Magna Carta, kong Johan Uden Land i 1215 underskrev, og op til Europas frie forfatninger i 1848, med forlængelse i internationale traktater om menneskeretsbeskyttelse ca. 100 år derefter. Og så er alligevel noget vigtigt sprunget over: Fredsbevægelsen i slutningen af 1800-tallet, som på en måde havde taget sin spæde begyndelse med oprettelsen af Røde Kors i 1863. Just forsøgene på at humanisere krigen 
og siden hen at forebygge den kan vel kaldes en ædel frugt af internationalismen.

Folkerettens 'fader', nederlænderen Hugo Grotius (1583-1645), påpegede allerede $\mathrm{i} 1625 \mathrm{i}$ sit store værk 'Om krigens og fredens ret', $D e$ jure belli ac pacis, at nok gjaldt der forskellige (rets) regler for krig og fred, men man skulle ikke være helt opgivende hvad angår krav til visse begrænsninger i krigsførelsen - af menneskelige grunde. Man tør sige, at folkeretten udviklede sig langsomt i retning af, hvad man i dag kalder dens 'tvingende normer', jus cogens, altså det, der internationalt er forbudt, uanset om denne og hin stat har tiltrådt en traktat herom.

Grundlæggende - eller måske snarere: et lang stykke hen ad vejen - er folkeretten en form for aftaleret, hvad der skal forstås på den måde, at de forpligtelser, de enkelte stater har påtaget sig, kun sker efter udtrykkeligt tilsagn. Selv om en international aftale er trådt i kraft, fordi så og så mange stater har tiltrådt den, binder den i almindelighed ikke andre end dem, der udtrykkeligt har ratificeret den. Og selv om de har gjort det, sker det jo ofte, at de ikke bekymrer sig en døjt om at overholde den. Således ratificerede Rwanda, Jugoslavien og Sudan konventionen mod folkedrab af 1948 adskillige år før, de faktisk begik folkedrab i 1990'erne og ind i dette årtusinde.

Mens den franske revolutions fan- fare-agtige motto om Frihed, lighed og broderskab vandt genklang uden for Frankrigs grænser, vil jeg vove den påstand, at man ikke kan overvurdere den betydning for international retsorden, det også fik, at den schweiziske forretningsmand Henry Dunant i $1859 \mathrm{kom}$ til at opleve de forfærdende virkninger af et slag, Frankrig og Italien udkæmpede mod Østrig nær den lille norditalienske by Solferino. Der fandtes ingen sanitetstjenester dengang, og det skønnes, at måske 40.000 sårede soldater kunne være reddet, hvis det havde været tilfældet.

Dunant tog initiativ til grundlæggelsen af Den Internationale Røde Kors Komité, der blev udarbejdet internationale regler til beskyttelse af syge og sårede soldater foruden om ambulancer og militære sygehuse. Da han siden led store tab ved fejlslagne investeringer i Algier, engagerede han sig i fredstanken uden dog at få afgørende indflydelse.

\section{Moderne folkeret}

Men hans - om end svage - fingeraftryk på to konferencer i Haag, i henholdsvis 1899 og 1907, må ikke undervurderes. Konferencerne mundede ud i to konventioner om krigens folkeret, herunder forbud mod dum-dum-kugler, giftgas og forgiftede våben samt fredelig bilæggelse af stridigheder, ligesom der blev oprettet en permanent voldgiftsdomstol, der den dag i dag har et sekretariat 
og fører lister over jurister i forskellige lande, der vil optræde som voldgiftsdommere - såfremt stater i indbyrdes strid, bliver enige om en sådan (diskret) pådømmelse af en tvist imellem dem.

Det lykkedes ikke inden Første Verdenskrig at få en planlagt international domstol (med en idealistisk bagtanke at forebygge krige) på plads, den etableredes først i 1922 i Haag under navnet Den permanente Domstol for Mellemfolkelig Retspleje. I 1920'erne satte fredstanken nye skud, selv om den første statslige fredsorganisation, Folkeforbundet, mildest talt hvilede på kviksand.

Skønt forsynet med den amerikanske præsident Woodrow Wilsons mange idealistiske ideer ville USA ikke være medlem, Tyskland meldte sig ud i 1933, Sovjetunionen blev ekskluderet i 1939. Inden da underskrev Frankrigs og USA's daværende udenrigsministre en aftale, der henviste konflikter til fredelig bilæggelse: Briand-Kellogg-pagten af 1928. En privat dansk forening, dannet i solidaritet med Folkeforbundet, tog mottoet 'fred ved ret'. Jo, troen på at forlænge retsstatsideen ud i den viden verden fejlede ikke noget.

Men ingen indsigtsfuld iagttager eller forsker i 1930'erne ville formentlig nære megen tiltro til fredstanken i en periode, hvor kommunismen, fascismen og nazismen voksede sig stærk i Sovjetunionen, Italien og Tyskland, samtidig med at mange andre stater i Europa havde diktatoriske regimer. Nogle separate aftaler med lande i Centraleuropa til beskyttelse af disses nationale mindretal fik ikke den store betydning. Men der var samtidig en spirende interesse for international retlig regulering i Latinamerika!

Ved Montevideo-konventionen af 1933 fastsattes sågar betingelserne for, hvornår en stat var blevet til. Nemlig, hvis den havde 1) et defineret territorium, 2) en statsbefolkning, 3) en regering med herredømme over territoriet (i tidligere tiders sprogbrug: udøvede suverænitet) og 4) såkaldt udenrigspolitiske handleevne, dvs. kunne indgå aftaler med andre lande.

Alt sammen rimelig fornuftigt folkeretligt arvegods, som nutiden mere eller mindre har kastet vrag på i en erkendelse af, at staters tilblivelse er ret så politisk og noget, man vanskeligt kan fastslå objektivt. Der var i øvrigt også diplomater, der på flere konferencer i Syd- og Mellemamerika vedtog deklarationer om noget, der faktisk blev forløbere for FN-pagten og FN-verdenserklæringen om menneskerettighederne og reelt tjente som inspiration for sidstnævntes nærmere udformning..

FN's 'grundlov', FN-pagten af 1945, slog strengt taget ikke noget stort slag for internationalismen - i hvert fald ikke hvis den skulle forstås som retten til at 'blande sig' $\mathrm{i}$ andres, dvs. andre landes, forhold. Thi allerede pagtens art.2,7 fastslog, at FN ikke skal gribe ind i, hvad der 
i det væsentlige hører ind under én stats jurisdiktion. Men den fik - i modsætning til Folkeforbundet - et 'styrehus' i form af Sikkerhedsrådet med visse særbeføjelser i tilfælde af krig. Brug af sanktioner mod 'uefterrettelige' stater blev sat i system om end dette middel ikke siden skulle vise sig særlig effektivt - undtagen måske over for Sydafrika.

Mens FN i nogle henseender kunne siges at være bagudrettet, for så vidt som den var grundlagt af 'de forenede nationer, allieret i kampen mod Aksemagterne', så igangsatte den af den nye verdensorganisation nedsatte Menneskeretskommission samtidig en udvikling, som på mange måder modererede eller måske næsten tog livet ud af nævnte art. 2,7. Særlig måske i Europa, hvor Europarådet af 1949 med sin europæiske menneskerettighedskonvention af 1950 og tilhørende Menneskerettighedsdomstol med tiden kom til at formulere en europæisk retspraksis på vitale områder - af stor betydning for Europas borgere.

Det skal lige med, at det store katalog af retsregler for krig, krigens folkeret, som Dunant - om man vil havde 'støbt kuglerne til', først i sin helhed blev formuleret på dette tidspunkt, nemlig i 1949 med fire såkaldte Røde Kors-Geneve-konventioner. Altså samtidig med - men uafhængig af - de internationale menneskerettigheder. Herefter fandtes der nu regler for krig såvel til lands, til søs som i luften og tillige for civil- befolkningen i krig såvel som i borgerkrig. At ingen af de mange regler rigtig definerede hvad en krigsforbrydelse var, måtte midlertidigt stå hen. Det særlige ved alle disse folkeretlige eksersitser var, at det ikke blev FN, men Den Internationale Røde Kors Komité (et rent schweizisk foretagende) der stod som en slags garant for overholdelsen af reglerne, ikke nogen af verdens stater. Det hele blev nu kaldt den humanitare folkeret, nyt navn for krigens folkeret, og i stort omfang formuleret af den schweiziske professor Jean Pictet. Alle disse regler henregnes i $\emptyset$ vrigt til folkeretlig sadvaneret, en mindre del af folkeretten, som antages at forpligte alle nationer uanset om de har tiltrådt specifikke traktater herom.

\section{Internationale strafferetsregler}

Strafbestemmelser for overtrædelser af den internationale ret blev først rigtig formuleret efter Anden. Verdenskrigs afslutning i 1945, da de hovedansvarlige i det nazistiske Tredje Riges og Japan skulle drages til ansvar. Men Nürnberg og Tokyotribunalernes domme skabte ikke bindende folkeret i tiden derefter om end en vis inspiration. Efter Første Verdenskrig var kun fulgt eksorbitante krav om krigsskadeserstatninger - som tabernationerne, særlig Tyskland, ingenlunde kunne honorere. Retsopgøret nu fik med andre ord ikke en fortsættelse i form 
af en 'afstraffelse' af den tyske og japanske befolkning. Vejen var på en måde banet for at Den Internationale Domstol, en fortsættelse af domstolen fra 1922, nu i FN-regi, måske kunne løse nogle af efterkrigstidens territorialkonflikter. Det blev det dog småt med. Den Kolde Krig med sin vældige kaprustning mellem $\emptyset_{\text {st }}$ og Vest, sin terrorbalance, gav international retslig regulering små muligheder.

Men idealismen fejlede igen ikke noget, og papiret var tålmodigt: I 1948 vedtog FN's Generalforsamling en international konvention mod folkedrab - Sovjetunionen ratificerede den allerede i 1953 og en bindende FN-konvention om borgerlige og politiske rettigheder i 1973, mens USA ventede til hhv. 1988 og 1992 med sine ratifikationer af disse to vigtige internationale aftaler.

Nå ja, vigtige? Måske alligevel ikke hvis man samtidig skelede til den politiske virkelighed: Sovjetunionen, som efter mange eksperters mening havde begået folkedrab over for flere folkeslag i Kaukasus - deriblandt tjetjenerne og Krim-tartarene - under Anden Verdenskrig, og som forfulgte talrige dissidenter i efterkrigsårene, idet det opretholdt det vældige GULAG-fangelejr-system, mens USA efter skelsættende højesteretsdomme efterhånden fik nedbrudt sin groteske forskelsbehandling af landets sorte befolkning.

Mens der altså indtil Jerntæppet gik op omkring 1990 ikke eksistere- de nogen international strafferet til at pådømme de alvorligste krænkelser af folkeretten, herunder den humanitære folkeret, gjorde den intereuropæiske beskyttelse af menneskerettighederne bestandige fremskridt, manifesteret ved det stadig stigende antal afgørelser fra Strasbourg-domstolen. Fra oprindelig ni medlemslande af Europarådet i 1949 er der i dag 47, som samtidig alle har ratificeret den europæiske menneskerettighedskonvention.

I dette 'system' - som et tilsvarende efter FN-konventionen om de borgerlige og politiske menneskerettigheder - kan individer indklage enhver af de ratificerende stater, samtidig med at staterne kan indklage hinanden. For FN's Menneskerettighedskomité dog kun med den følge, at der i sidste ende gives en meningstilkendegivelse om, hvorvidt der foreligger konventionskrænkelse; modsat tilpligtes en stat, der har krænket i Europa-systemet at betale godtgørelse til den krænkede (person eller evt. organisation).

Kun få af Europa politiske konflikter har givet anledning til de såkaldte stat-mod-stat-klager - totalt omkring 20, siden Den Europæiske Menneskerettighedsdomstol begyndte sin virksomhed i 1958. Det vakte stor opmærksomhed, da Danmark, Norge, Sverige og Holland i 1967 og 70 rejste sag mod Grækenland, der efter oberstkuppet i 1967 var gået fra demokrati til diktatur med krænkelse af en hel stribe fun- 
damentale menneskerettigheder. De fire lande havde ikke noget 'i klemme' i forholdet til Grækenland, men følte et ansvar i overensstemmelse med konventionens art. 33, der giver signatarstaterne ret til at indbringe "ethvert påstået brud på konventionen og de dertil knyttede protokoller" (i alt ca. 30 specifikke menneskerettigheder. red.) for domstolen.

Europarådets Parlamentariske Forsamling kaldte det nærmest en pligt at anlægge sag ved alvorlige krænkelser. Det må kaldes udtryk for det misbrug af udtryk som 'pligt' og 'ansvar', som hyppigt forekommer i internationale fora. FN-generalsekretær Ban Ki-moon formulerede således i 2008 en ny folkeretlig maxime om "staters ansvar vedrørende beskyttelse af truede befolkninger", hvormed han nærmest 'flyttede' den spirende ret til humanitær intervention (i fremmede lande) hen til pligtens område.

I betragtning af hvor stor diskussion NATO-staternes humanitære intervention i Kosovo i 1999 vakte (især fordi den ikke var sanktioneret af FN's Sikkerhedsråd), og hvordan visse eksperter stadig finder det betænkeligt, at Serbien blev bombarderet for at frelse kosovo-albanernes fra et overhængende folkedrab fra serbisk side, virker det ejendommeligt, at der så ofte tales om 'staters pligter efter folkeretten' - pligterne drejer sig, når det kommer til stykket, overvejende om alt det de ikke må!

\section{Ingen eksklusion}

Europarådslandene har ikke siden de dengang gjorde skridt til at ekskludere Grækenland af Europarådet (idet dette land dog kom en afgørelse i fork øbet ved selv at melde sig ud), valgt at benytte dette krasse våben. Tyrkiet med sine mange sager om tortur og henrettelser - fastslået ved talrige afgørelser af Strasbourg-domstolen - kunne vel gøre sig 'fortjent' til en lignende behandling.

At følge eksemplet fra Grækenland (som dog kun var uden for rådet 1969-74) skønnes ikke formålstjenligt, og der har således heller ikke været optræk til at Rusland med sine mange krænkelser, ikke mindst ved bortførelse og henrettelser af tjetjenere - skulle ekskluderes. Udsigten til at påvirke Rusland i retning af retsstat og demokrati skønnes større, så længe det er medlem. Men drab på journalister, politikere og menneskerettighedsforkæmpere har i allerhøjeste grad opskræmt sindene.

Det har lidet hjulpet, at landet har fået et nævningesystem, for når folk én gang er blevet tiltalt ved en domstol, frifindes de næsten aldrig. Ifølge professor Sergej Pasjin, Institut for $ø$ konomi, politik og jura, Moskva, sker det kun i 1,5 pct. af tilfældene. Et stort antal russere har fået hjælp af Strasbourg-domstolen til at få udbetalt løn, som den russiske stat ikke har udbetalt dem, trods 
domme ved russiske retsinstanser.

Men nu resterer der over 700 af den slags sager i Strasbourg, så Rusland har fået besked om at få has på disse sager inden udgangen marts 2010. Hvis ikke, vil Europarådets Ministerkomité så tale dunder. Menneskerettighedsdomstolen, som afsiger ca. 1500 domme om året, ønsker inderligt at blive befriet for trivielle, repetitive og bagatelagtige sager, og har da også fået 46 staters tilslutning til en tillægsprotokol herom - kun Rusland vægrer sig ved at ratificere protokollen. Indtil det sker, vil domstolen være overbebyrdet med sager.

\section{Indsatsen skal ikke forklejnes}

Som ovenfor antydet har Den Internationale Domstol i Haag ikke løst større brændbare problemer i denne verden, endsige hindret omfattende krige. Dens virke skal dog på ingen måde forklejnes, for den har eksempelvis medvirket til, at en række stridigheder om øers tilhørsforhold og søterritoriers udstrækning ikke er eskaleret.

Den afgjorde i 1980 den ulovlige 444 dage lange iranske besættelse af den amerikanske ambassade i Teheran til USA's fordel (nemlig som en krænkelse af den immunitet en ambassade og dens personale nyder efter folkeretten), mens den i 1986 fandt USA skyldig i krænkelse af den folkeretlige sædvaneret ved udlægning af miner i Nicaraguas havne mv. som støtte for de såkaldte kontra'er, den guerilla-styrke, som fra nabolandet Honduras rettede angreb på nicaraguanske myndigheder. Inden for de næste par år vil domstolen efter anmodning af Serbien fremlægge et responsum om, hvorvidt det var folkeretsmæssigt, at Kosovo i 2008 løsrev sig fra Serbien.

Domstolen fastslog i 2007, at Serbien havde en vis medskyld ved ikke at have hindret de bosnisk-serbiske militærenheders folkedrab på bosniakkerne i Bosnien-Hercegovina, men pålagde ikke Serbien et direkte ansvar for at have udløst folkedrabet. En bosnisk-serbisk general er som den hidtil eneste dømt for folkedrab af Straffetribunalet for Eksjugoslavien i Haag, mens der er faldet ca. 35 andre domme, hvor personer er dømt for krigsforbrydelser og forbrydelser mod menneskeheden under Balkan-krigene i 1990'erne (det kræver en bevist hensigt om helt eller delvis at udrydde en folkegruppe af nationale, etniske, racemæssige eller religiøse grunde, hvilket ofte er svært at bevise).

Straffetribunalet vedrørende Rwanda har i i alt 35 sager dømt 12 personer for folkedrab. Ved begge tribunaler er ca. 60 personer derudover blevet dømt for alvorlige krænkelser af folkeretten, herunder drab, tortur, deportationer mv.

Ved flere andre specialtribunaler står ledende politiske skikkelser for tidligere blodige diktaturer i dag tiltalt, således bl.a. liberianeren Charles Taylor ved Sierra Leone-tribuna- 
let og torturbødlen Kaing Guek Eav ved Cambodja-tribunalet. Sudans præsident Omar al-Bashir blev i marts 2009 - efter godkendelse af FN's Sikkerhedsråd - ved den nye Internationale Straffedomstol i Haag tiltalt for krigsforbrydelser og forbrydelser mod menneskeheden som led i Sudans nedkæmpelse af bønderne i Darfur-provinsen. Det er skelsættende nyt i folkeretten, at siddende præsidenter kan tiltales for internatonale domstole.

Skellet mellem jura og politik er i mange tilfælde hårfint. Den danske rigsrets dom over tidligere justitsminister Erik Ninn-Hansen viste, at selv en advokat, der var blevet folketingsmedlem, ikke kunne skelne mellem lovens påbud og en politikers begrænsninger. Men hvis politikerne ikke - både nationalt og internationalt - blev bremset af et større sæt retsregler, ville demokratierne ikke kunne virke. Krige vil aldrig kunne undgås, men mellem stater er de efter Anden Verdenskrig blevet reduceret til et minimum. At fremme humanitære principper i borgerkrige er til gengæld uhyre vanskeligt.

Mange internationale aftaler, herunder FN's børnekonvention, anti-slaverikonventionen, Røde Kors-konventionerne m.fl., kommer her ofte ulykkeligvis til kort. Budskabet om at livsvilkår kan ændres, at livegenskab ikke er uforanderligt, at kasteskel kan fjernes - for nu blot at nævne nogle få inkarnerede plager - er vigtigt at bringe rundt i verden.

Henrik Døcker er journalist, specialiseret i international politik, folkeret og menneskerettigheder. Han har bl.a. skrevet bogen 'Menneskeret i Europa' (2. udgave 2003). 